\title{
Failure Mode and Effect Analysis (FMEA) of Pneumatic System of CNC Milling Machine
}

\author{
Yudi Dwianda ${ }^{\text {a,* }}$ \\ a) Maintenance and Repair Engineering Department, Politeknik Kampar, Indonesia \\ *Corresponding author: dwianda@gmail.com
}

\section{Paper History}

Received: 18-January-2021

Received in revised form: 30-February-2021

Accepted: 30-March-2021

\begin{abstract}
The purpose of this study is to determine the type of failures, the causes, as well as efforts and proposed actions that can be taken to improve the performance of the pneumatic system of CNC milling machines. The Failure Mode and Effect Analysis (FMEA) method is used to find priority problems through Risk Priority Number (RPN) for pneumatic system of components of CNC milling machine. The results of critical component analysis were a leakage occurs in pneumatic valve component, which the most critical risk of the RPN value. It potential failure was caused the high humidity and poor air quality from the compressor, which the RPN of 392 and 384 respectively. The proposed improvement was the replacement of damaged components and optimizing the preventive maintenance, which follow the right operation and maintenance procedures recommended as suggested by the manufacturer.
\end{abstract}

KEY WORDS: $C N C$ Milling Machine, FMEA, Pneumatic system, RPN.

\subsection{INTRODUCTION}

The CNC machine is controlled by computers that use numeric codes, symbols, and letters as command data, which mainly composed of the mechanical system, electrical system, hydraulic and pneumatic system, and air feed system. The combination of mechanical systems and computers will produce products that are more precise, faster and can be used for mass production [1]. The damage to a $\mathrm{CNC}$ machine is likely to be a failure caused by mechanical systems, hydraulic systems, pneumatic systems, main transmission, electrical and electronic systems, and cooling systems [2]. In term of pneumatic system such as the pneumatic valve component responsible for controlling the pressure, rate, and amount of air as it moves through a pneumatic system. The pneumatic valve is controlled by signal to compress air as power source and use cylinder as actuators to drive the valve. The causes of failures caused by hydraulic and pneumatic systems are leakage, component damage, excess pressure, overflow, overheating and noise [3]. Identification of one of the failures requires an analysis of the method failure about the component's function such as Failure Mode and Effect Analysis (FMEA).

The FMEA method aims to show the potential failure modes and show the causes and effects of these modes so as to identify to reduce the possibility of failure. Failure Mode and Effect Analysis (FMEA) is a method used to find priority solutions based on a description of top event problems and a combination of problem events and their causes [4]. In the FMEA process, priority settlement based on Risk Priority Number (RPN) will be sought for each problem that occurs [5]. The purpose of applying the FMEA method according to Stamatis [6] is to identify the failure modes, causes, and consequences of these failures, so that they can help in reducing and preventing the emergence of other problems. FMEA stage is carried out after obtaining a description of the problem in the system, as well as the combinations of causes of the problem known so that priority can be sought for solving problems that occur in the system [7]. The failure mode and effect analysis can help control maintenance and prevent the cause of critical failure. Based on [8], good maintenance management must consider every failure mode in the system, the effect of the failure mode and its critical analysis.

Some study was conducted by researchers to implementation of the FMEA methods of the CNC machines. Filip [7] used the FMEA method to identify and reduce potential problems of a system, subsystem and component of CNC machines. Kulkarni and Shrivastava [9] was used the FMEA approach to improve machinery system reliability and operational safety for CNC grinding machine. Peng [1] was done the study to prediction of failures on CNC machine based on FMEA method to analysis of CNC machines failure mode on safety. Wang et al [10] employed FMEA to compute feed systems of the CNC machine using the critical values and prioritize failures. In this paper is proposed to analyze the failure modes of pneumatic system of CNC milling machine using FMEA method. 


\subsection{METODOLOGI}

The data collection was carried out by means of direct interviews with machine operators. The information of FMEA for $\mathrm{CNC}$ machine was collected through form by respective experts and maintenance team. In this paper was focused to investigate the FMEA of pneumatic valve of CNC milling machine. The procedures and stages of implementing the Failure Mode and Effect Analysis (FMEA) method are as follows:

1. Determination of the function of the CNC Milling machine was done to determine the function of each component failure.

2. The potential failure modes of each component to be analyzed to find out what types of failures occur in the machine components and potential failures that would be occurred. From the results of the interview with the machine operator, it was known the potential failure mode of the failure $\mathrm{CNC}$ machine components.

3. Determine the effects of failure for each failure mode were caused by damaging of the components that was occurred on CNC Milling machine. Based effects of failure data can be seen the severity of the effects of these failures. The severity of the failure effect or severity value was done in a separate assessment. The value of severity assessment was a ranking of 1 for the lowest and 10 for the highest. The ranking of severity can be seen in Table 1 .

Table 1: The ranking of severity criteria [3]

\begin{tabular}{|c|c|c|}
\hline Number & Effect & Severity Criteria \\
\hline 10 & $\begin{array}{l}\text { Hazardous } \\
\text { without warning }\end{array}$ & $\begin{array}{l}\text { Hazardous without warning very high } \\
\text { severity ranking: Affects operator, } \\
\text { plant or maintenance personnel; } \\
\text { safety and/or effects noncompliant. }\end{array}$ \\
\hline 9 & $\begin{array}{l}\text { Hazardous with } \\
\text { warning }\end{array}$ & $\begin{array}{l}\text { High severity ranking: Affects } \\
\text { operator, plant or maintenance } \\
\text { personnel; safety and/or effects } \\
\text { noncompliant. }\end{array}$ \\
\hline 8 & $\begin{array}{l}\text { Very high } \\
\text { downtime or } \\
\text { defective parts }\end{array}$ & Downtime of more than 8 hours. \\
\hline 7 & $\begin{array}{l}\text { High downtime } \\
\text { or defective parts }\end{array}$ & Downtime of more than 4-7 hours. \\
\hline 6 & $\begin{array}{l}\text { Moderate } \\
\text { downtime or } \\
\text { defective parts }\end{array}$ & Downtime of more than 1-3 hours. \\
\hline 5 & $\begin{array}{l}\text { Low downtime } \\
\text { or defective parts }\end{array}$ & Downtime of 30 minutes to 1 hour. \\
\hline 4 & Very low & $\begin{array}{l}\text { Downtime up to } 30 \text { minutes and no } \\
\text { defective parts. }\end{array}$ \\
\hline 3 & Minor effect & $\begin{array}{l}\text { Process parameters variability } \\
\text { exceeds upper/lower control limits; } \\
\text { adjustments or process controls need } \\
\text { to be taken. No defective parts. }\end{array}$ \\
\hline 2 & $\begin{array}{l}\text { Very minor } \\
\text { effect }\end{array}$ & $\begin{array}{l}\text { Process parameters variability within } \\
\text { upper/lower control limits; } \\
\text { adjustments or process controls need } \\
\text { to be taken. No defective parts. }\end{array}$ \\
\hline 1 & No effect & $\begin{array}{l}\text { Process parameters variability within } \\
\text { upper/lower control limits; } \\
\text { adjustments or process controls not } \\
\text { needed or can be taken between shifts } \\
\text { or during normal maintenance visits. } \\
\text { No defective parts. }\end{array}$ \\
\hline
\end{tabular}

4. Determine the cause of failure of damaged CNC milling machine components were be searched for potential causes of failure. From the potential causes of failure that have been obtained, the next step is to determine the frequency of occurrence of the cause of failure or occurrence value. To assess the value of occurrence is to provide a ranking of values starting from the value of 1 for the lowest to the value of 10 for the highest. Ranking of occurrence values can be seen in Table 2.

Table 2: Ranking of occurrence values criteria [12]

\begin{tabular}{cll}
\hline Number & Probability of failure & \multicolumn{1}{c}{ Criteria } \\
\hline $9-10$ & Very high & Failure is almost inevitable \\
$7-8$ & High & Repeated failure \\
$5-6$ & Moderate & Occasional failure occurs \\
$3-4$ & Low & Relatively few failures occurred \\
$1-2$ & Remote & Failure unlikely \\
\hline
\end{tabular}

5. Detection of failure modes is a procedure to detect the failure of a product. The ranking of detection ratings is from 1-10. The ranking of the detection level assessment criteria can be seen in Table 3.

Table 3: The ranking of detection criteria [13]

\begin{tabular}{|c|c|c|}
\hline Number & Detection & Criteria \\
\hline 10 & $\begin{array}{l}\text { Almost } \\
\text { certainly } \\
\text { never }\end{array}$ & $\begin{array}{l}\text { The control or machine cannot detect the } \\
\text { potential cause and subsequent failure mode or } \\
\text { does not exist in the machine design or control. }\end{array}$ \\
\hline 9 & $\begin{array}{l}\text { Very } \\
\text { small }\end{array}$ & $\begin{array}{l}\text { It is very unlikely that the design, control or } \\
\text { machine will detect potential causes and } \\
\text { subsequent failure modes. }\end{array}$ \\
\hline 8 & Small & $\begin{array}{l}\text { It is unlikely that the design, control or machine } \\
\text { will detect potential causes and subsequent failure } \\
\text { modes and machine control will provide an } \\
\text { indication of the failure. }\end{array}$ \\
\hline 7 & Very low & $\begin{array}{l}\text { Very low possibility of design, control or } \\
\text { machine will detect potential causes and } \\
\text { subsequent failure modes and machine control } \\
\text { will prevent failure that will occur. }\end{array}$ \\
\hline 6 & Low & $\begin{array}{l}\text { Low possibility of design, control or machine will } \\
\text { detect potential causes and subsequent failure } \\
\text { modes and machine control will prevent failures } \\
\text { that will occur. }\end{array}$ \\
\hline 5 & Moderate & $\begin{array}{l}\text { While the possibility of design, control or } \\
\text { machine will detect potential causes and } \\
\text { subsequent failure modes and machine control } \\
\text { will prevent the failure that will occur and isolate } \\
\text { the caused. }\end{array}$ \\
\hline 4 & $\begin{array}{l}\text { Moderatel } \\
\text { y high }\end{array}$ & $\begin{array}{l}\text { The chances are high that the design, control or } \\
\text { machine will detect potential causes and } \\
\text { subsequent failure modes and machine control } \\
\text { will prevent the failure that will occur and isolate } \\
\text { the cause. Machine control may be needed. }\end{array}$ \\
\hline 3 & High & $\begin{array}{l}\text { The high possibility of design, control or machine } \\
\text { will detect potential causes and subsequent failure } \\
\text { modes and machine control will prevent the } \\
\text { failure that will occur and isolate the cause. } \\
\text { Machine control may be needed. }\end{array}$ \\
\hline 2 & Very high & $\begin{array}{l}\text { Very high the possibility of design, control or } \\
\text { machine will detect potential causes and } \\
\text { subsequent failure modes. Machine control is not } \\
\text { required. }\end{array}$ \\
\hline 1 & $\begin{array}{l}\text { Almost } \\
\text { certain }\end{array}$ & $\begin{array}{l}\text { Design, control can almost certainly detect } \\
\text { potential causes and subsequent failure modes. } \\
\text { Machine control is not required. }\end{array}$ \\
\hline
\end{tabular}

6. Calculate the Risk Priority Number (RPN). The RPN can be calculated by combining severity, occurrence, and detection 
values. Based the RPN value was be known the critical component position and the priority for corrective or component replacement actions. The formula for determining the RPN value is $[6 ; 11]$ :

$\mathrm{RPN}=\mathrm{S}$ (Severity) $\mathrm{x} \mathrm{O}$ (Occurrence) $\times \mathrm{D}$ (Detection)

\subsection{RESULT AND DISCUSSION}

\subsection{Results}

The analysis of the problems that occur on the CNC milling machine based on the identification of damage by the FMEA method to obtain a proposed action on the factors causing the failure. The pneumatic systems of CNC milling damages might be valve, air regulator, air lubricator and pneumatic cylinder.

Based on interviews was conducted to machine operators, a list of damage to $\mathrm{CNC}$ milling machine components and the types of damage for pneumatic systems such as:

(1) Pneumatic unit of Automatic Tool Changer (ATC) has leaked of seal; it effected the failure tool change automatically.

(2) Pneumatic cylinder has leaked of seal; it effected mechanism cannot function properly.

(3) Pneumatic valve leaking has caused a loss of pressure; it effected the mechanism in the pneumatic system cannot work.

The potential causes in the pneumatic systems, namely:

- the air regulator is not discharged;

- poor air quality from the compressor;

- the lubricator air tube is empty;

- air filters do not work;

- aging component

- high humidity;

- clogging of contaminants;

- seal experiencing extreme stress.

- inadequate lubrications

- contaminant of air supply

- extreme pressure spikes

- rod ends bend or break

Critical Risk Analysis Using the FMEA for Pneumatic System of CNC Milling Machine

The Failure Mode and Effect Analysis (FMEA) method was employed to determine the most critical risk that causes a failure of pneumatic systems of CNC Milling machine. The critical risk was used as a reference, so that action can be obtained in the form of proposed improvements. To determine the most critical risk of damage that occurs first was determined the value of the seriousness of the level of damage (severity), the value of the probability of the occurrence of damage, the value of detection of failures that occur, and the value of Risk Priority Number (RPN).

The Severity (S) value is a value that is used to determine how serious the effects caused by the damage. The assessment of the seriousness of the effects starting from 1 to 10 depends on how serious the effects are from the damage. Assess the seriousness of the effects caused using the severity values specified in Table 1.
The value of occurrence $(\mathrm{O})$ is an assessment that is used to find out how often the frequency probability of the cause of failure results in failure. The value of occurrence values starts from 1 to 10 depending on how often it occurs. Assessment of the value of this occurrence has been determined and can be seen in Table 2. Detection value (D) is an assessment of the detection of potential failures and failures that will occur. Detection value assessment is set between numbers 1 to 10 . Rating detection value has been set, can be seen in Table 3.

After getting a list of failure risks along with the sequence of events that caused the failure, then the severity, occurrence, and detection values are determined. Determination of severity, occurrence, and detection values are based on each predetermined criterion. After the values of severity, occurrence, and detection are obtained, the next step is to calculate the Risk Priority Number (RPN) value. The RPN assessment is carried out to determine the risks that are priority priorities for completion. The value of severity, occurrence, detection, and RPN assessment can be seen in Table 4.

\subsection{Discussion}

The severity value of potential failure mode of each component is presented in Figure 1. The pneumatic valve component of CNC milling machine has the highest severity value that is 8 . The pneumatic valve can caused the highest severity effect on component damage that occurs on CNC milling machine. The pneumatic valve functions to regulate pressure and has a potential failure to make pressure drop. Therefore, damaging this component can caused not function, which acts as a regulator or control of air in the pneumatic system.

The pneumatic unit of ATC and pneumatic cylinder has potential mode to seal leakage. Both of this has moderate downtime or defective parts with severity number of 6 .

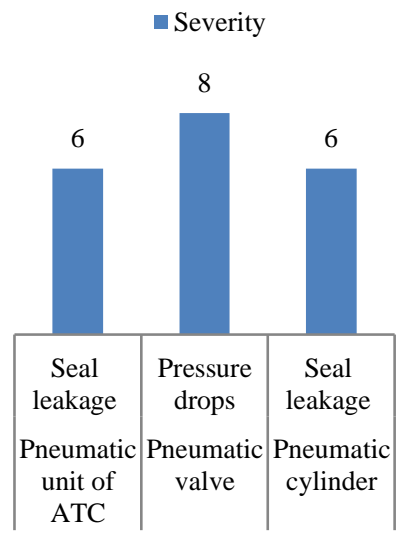

Figure 1: The Components and Potential Failure Mode of Severity Values

The occurrence value is the value of how often the failure can caused result in a failure. In Figure 2 is presented the frequency level of potential failure causes of the pneumatic unit of ATC component. The type of potential failure that most often causes failure that is the water contamination in air regulator, which the occurrence value of 8 , detection value of 4 and RPN of 192. In Figure 2 can be seen the most value criticality level of potential failure causes in CNC milling machines for pneumatic unit of ATC component. The cause of the biggest potential failure is due to the poor air quality from the compressor with an RPN value of 294 
(C) 2012 ISOMAse, All rights reserved

Table 4: The Values of Severity, Occurrence, Detection and RPN of Pneumatic Systems of CNC Milling Machine

\begin{tabular}{|c|c|c|c|c|c|c|c|c|}
\hline Component & Function & $\begin{array}{l}\text { Potential } \\
\text { failure } \\
\text { mode }\end{array}$ & $\begin{array}{l}\text { Effects of } \\
\text { potential } \\
\text { failure }\end{array}$ & SEV & Causes of potential failure & $\mathrm{OCC}$ & DET & RPN \\
\hline \multirow{5}{*}{$\begin{array}{c}\text { Pneumatic } \\
\text { unit of } \\
\text { ATC }\end{array}$} & \multirow{5}{*}{$\begin{array}{l}\text { Regulated } \\
\text { pressure }\end{array}$} & \multirow{5}{*}{$\begin{array}{c}\text { Seal } \\
\text { leakage }\end{array}$} & \multirow{5}{*}{$\begin{array}{l}\text { Cutting tools } \\
\text { cannot } \\
\text { change } \\
\text { automatically }\end{array}$} & \multirow{5}{*}{6} & $\begin{array}{l}\text { Water contamination in air } \\
\text { regulator }\end{array}$ & 8 & 4 & 192 \\
\hline & & & & & $\begin{array}{l}\text { Poor air quality from the } \\
\text { compressor }\end{array}$ & 7 & 7 & 294 \\
\hline & & & & & $\begin{array}{l}\text { The tubular lubricator is } \\
\text { empty }\end{array}$ & 4 & 3 & 72 \\
\hline & & & & & Air filter does not work & 6 & 5 & 180 \\
\hline & & & & & Aging component & 4 & 3 & 96 \\
\hline \multirow{6}{*}{$\begin{array}{l}\text { Pneumatic } \\
\text { valve }\end{array}$} & \multirow{6}{*}{$\begin{array}{l}\text { Regulated } \\
\text { pressure }\end{array}$} & \multirow{6}{*}{$\begin{array}{l}\text { Pressure } \\
\text { drops }\end{array}$} & \multirow{6}{*}{$\begin{array}{l}\text { Clamping } \\
\text { system is not } \\
\text { workable }\end{array}$} & \multirow{6}{*}{8} & $\begin{array}{l}\text { Water in the air regulator is } \\
\text { not removed }\end{array}$ & 7 & 4 & 224 \\
\hline & & & & & $\begin{array}{l}\text { The lubricator air tube is } \\
\text { empty }\end{array}$ & 5 & 7 & 280 \\
\hline & & & & & Air filters do not work & 5 & 6 & 240 \\
\hline & & & & & $\begin{array}{l}\text { Poor air quality from the } \\
\text { compressor }\end{array}$ & 8 & 6 & 384 \\
\hline & & & & & High humidity & 7 & 7 & 392 \\
\hline & & & & & Aging component & 4 & 4 & 128 \\
\hline \multirow{6}{*}{$\begin{array}{l}\text { Pneumatic } \\
\text { cylinder }\end{array}$} & \multirow{6}{*}{$\begin{array}{l}\text { Regulated } \\
\text { pressure }\end{array}$} & \multirow{6}{*}{$\begin{array}{l}\text { Seal } \\
\text { leakage }\end{array}$} & \multirow{3}{*}{$\begin{array}{l}\text { Required } \\
\text { pressure not } \\
\text { developed }\end{array}$} & \multirow{3}{*}{6} & Inadequate lubrications & 4 & 6 & 192 \\
\hline & & & & & Clogging of contaminants & 7 & 8 & 336 \\
\hline & & & & & $\begin{array}{l}\text { Seals experiencing extreme } \\
\text { stress }\end{array}$ & 7 & 6 & 252 \\
\hline & & & \multirow{3}{*}{$\begin{array}{l}\text { Improper job } \\
\text { clamping }\end{array}$} & \multirow{3}{*}{6} & Contaminant of air supply & 8 & 7 & 336 \\
\hline & & & & & Extreme pressure spikes & 3 & 3 & 54 \\
\hline & & & & & Rod ends bend or break & 2 & 3 & 36 \\
\hline
\end{tabular}

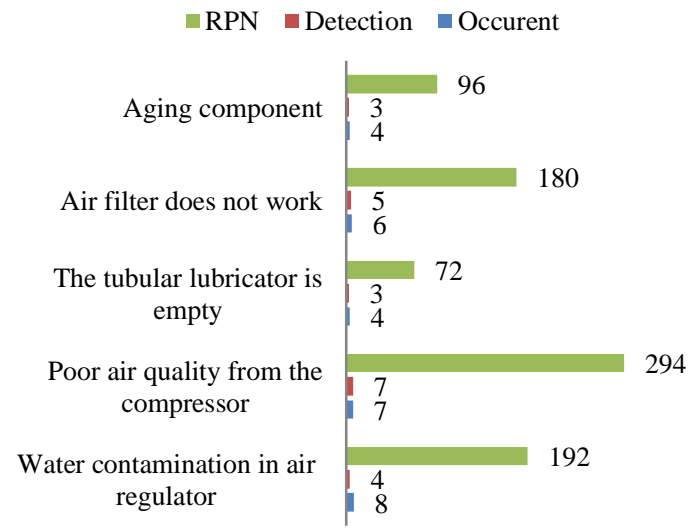

Figure 2: The Values of Occurrence, Detection and RPN of Pneumatic unit of ATC

In Figure 3 is presented the frequency level of potential failure causes of the pneumatic valve component. The type of potential failure that most often causes failure that is poor air quality from the compressor. It has the occurrence value of 8 , detection value of 6 and RPN of 384. In Figure 2 can be seen the most value criticality level of potential failure causes in $\mathrm{CNC}$ milling machines for pneumatic valves. The cause of the biggest potential failure is due to the high humidity with an RPN value of 392.

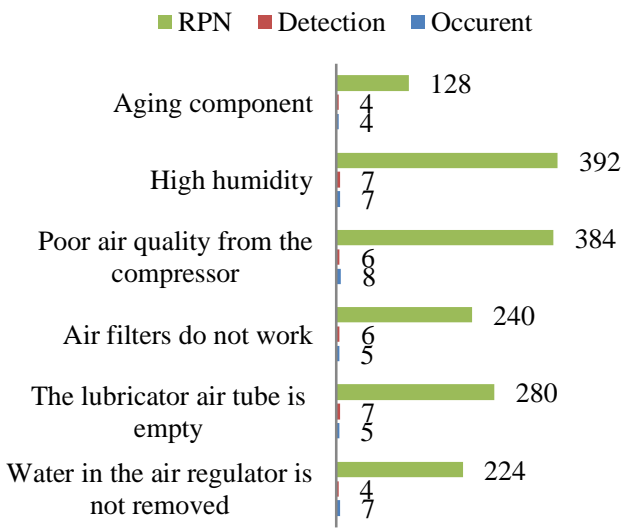

Figure 3: The Values of Occurrence, Detection and RPN of Pneumatic Valve Component

The frequency level of potential failure causes of the pneumatic cylinder component is depicted in Figure 4. The type of potential failure that most often causes failure that is contaminant of air supply. It has the occurrence value of 8 , detection value of 7 and RPN of 336. Also, the most value criticality level of potential failure causes in CNC milling machines for pneumatic cylinder component is due to the clogging of contaminants with an RPN value of 336 . 


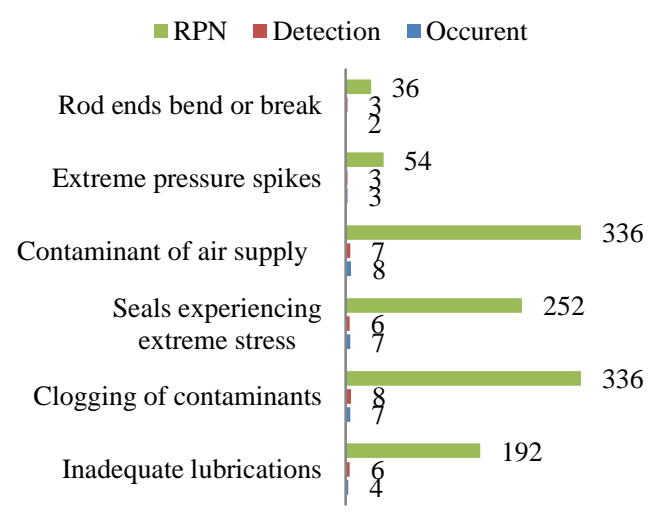

Figure 4: The Values of Occurrence, Detection and RPN of Pneumatic Cylinder Component

\subsection{CONCLUSION}

Based the FMEA method for pneumatic systems of CNC milling machine is revealed the most RPN of high humidity (392) and poor air quality from the compressor (384). Both of them are potential failure mode for pneumatic valve component, which function to regulate pressure. This component has potential failure as the effect to pressure drops and make the clamping system that is not workable. So, the handling / repair action is needed to improve and reduce the risk that will arise on the pneumatic valve components. Proposed actions that need to be taken, such as: replacement of leaking pneumatic valves; repair of the intake air source in the pneumatic system; water that settles on the air regulator is removed; maximizing the use of an air dryer on the air source before the air enters the pneumatic system, so that the incoming air is drier. Finally, carry out the maintenance activities according to procedures recommended by the manufacturer and adopt the preventive maintenance.

\subsection{REFERENCE}

[1] Peng C., Lan, L., Liu Q. and Yao, J. (2013). Research on soft fault of computer numerical control system, Chemical Engineering Transactions, Vol.33: 973-978.

[2] Salvi, R.K. and Jindal, S. (2017). FMEA to enhance quality and efficiency of CNC machines: a case study in valve manufacturing industry, Industrial Engineering Journal, Vol.10, No.4, pp: 35-41.
[3] Degu, Y.M. and Moorthy, R.S. (2014). Implementation of machinery failure mode and effect analysis in Amhara Pipe Factory P.L.C., Bahir Dar, Ethiopia, American Journal of Engineering Research, Vol.03, No.1, pp: 5763.

[4] Ambekar, S.B., Edlabadkar, A. and Shrouty, V. (2013). A review: implementation of failure mode and effect analysis, International Journal of Engineering and Innovative Technology, Vol.2, No.8, pp: 37-41.

[5] Liu, H.C., Liu, L. and Liu, N. (2013). Risk evaluation approaches in failure mode and effects analysis: A literature review, Expert Systems with Applications, Vol.40, pp: 828-838.

[6] Stamatis, D.H. (1995). Failure Mode and Effect Analysis : from Theory to Execution. ASQC Quality. Milwauke. USA.

[7] Filip, F.C. (2011). Theoretical research on the failure mode and effect analysis (fmea) method and structure, Advances in Manufacturing Engineering, Vol.2, pp: 176181.

[8] Gupta, G., Mishra, R., (2017). A failure mode effect and criticality analysis of conventional milling machine using fuzzy logic: case study of RCM, Quality and Reliability Engineering International, Vol. 33, pp: 347-356.

[9] Kulkarni, P.V. and Shrivastava, R.K. (2013). Failure mode and effect analysis: process capability enhancement-a case study, International Journal of Engineering Research and Technology, Vol.2, No.4, pp: 1859-1868.

[10] Wang, X., Zhang, Y., Shen, G. (2016). An improved FMECA for feed system of CNC machining center based on ICR and DEMATEL method, The International Journal of Advanced Manufacturing Technology, Vol. 83, pp: 43-54.

[11] Ebrahemzadih, M., Halvani, G.H., Shahmoradi, B. and Giahi, O. (2014). Assessment and risk management of potential hazard by failure mode and effect analysis (fmea) method in yazd steel complex, Journal of Safety Science and Technology, Vol.4, pp: 27-135.

[12] Anes, V., Henriques, E., Freitas, M. and Reis, L. (2018). A new risk prioritization model for failure mode and effects analysis, Quality and Reliability Engineering International, Vol.34, pp:516-528.

[13] Ghivaris, G.A, Leksananto, K. dan Desrianty, A. (2015). Usulan perbaikan kualitas proses produksi rudder tiller di pt. pindad bandung menggunakan fmea dan fta, Jurnal online Institute Teknologi Nasional, Vol.4, No.3, pp: 7384. 